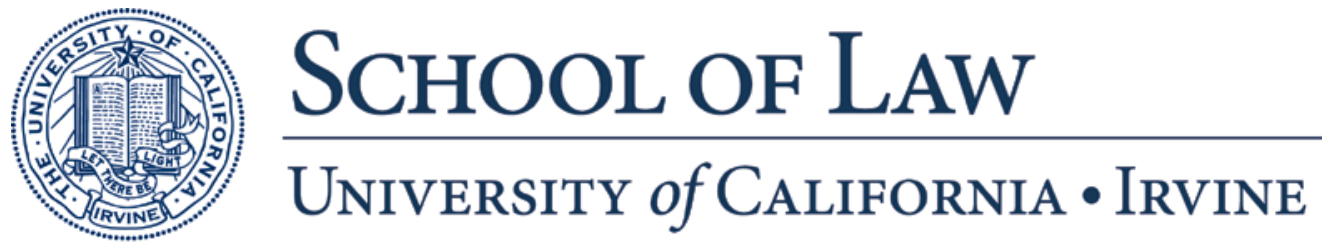

Legal Studies Research Paper Series No. 2015-28

\title{
Direct participation: Law school clinics and international humanitarian law
}

\author{
David Kaye \\ dkaye@law.uci.edu \\ University of California, Irvine School of Law
}

The paper can be downloaded free of charge from SSRN at: 


\title{
Direct participation: Law school clinics and international humanitarian law
}

\section{Laurie R. Blank and David Kaye}

Laurie Blank is a Clinical Professor of Law and Director of the International Humanitarian Law Clinic at Emory University School of Law.

David Kaye is a Clinical Professor of Law at the University of California, Irvine School of Law. In June 2014, the United Nations Human Rights Council appointed him Special Rapporteur on the Protection and Promotion of the Right to Freedom of Opinion and Expression.

\begin{abstract}
Law school clinics focused on international humanitarian law (IHL) enable students to participate directly in the development and application of IHL through concrete "real world" work-from training to research and fact-finding, litigation to high-level advocacy, and many spaces in between. These opportunities do far more than just contribute to these students' development as effective, reflective lawyers, certainly a key goal of any clinical environment. Clinical IHL work also matches clinical pedagogy with cutting-edge issues in armed conflict to deepen students' law school experiences and enables them to engage in the IHL goals of promotion, implementation and enforcement.
\end{abstract}

Keywords: international humanitarian law, clinic, promotion, clinical education, law of armed conflict, Geneva Conventions.

In recent years, just as international humanitarian law (IHL) has entered the mainstream of international legal education in the United States, students and faculty have moved beyond the classroom and have integrated IHL work into clinical learning. Consider some examples: 
- Students work with military and civilian faculty at Marine Corps University and the Naval War College to design simulation exercises and ethical decision games that incorporate IHL. They research and draft comprehensive discussion guides for legal seminars during junior officer courses. ${ }^{1}$

- Students, collaborating with a California-based Cambodian-American nongovernmental organization (NGO), work with survivors of the Khmer Rouge regime who now live in the United States, helping hundreds to complete victim participation forms that identify alleged violations of IHL under the jurisdiction of the Extraordinary Chamber in the Courts of Cambodia (ECCC), or Khmer Rouge Tribunal. They deliver over 200 such forms to the ECCC in Phnom Penh, and these serve as the basis for several victims to participate in judicial proceedings. ${ }^{2}$

- In light of the events of the uprisings in the Arab world, students work with a Berlin-based human rights NGO to analyze whether the violence accompanying protests in specific countries triggered the existence of noninternational armed conflicts and constituted crimes against humanity in order to analyze options for accountability. ${ }^{3}$

- Students work with activists in a Washington, DC-based NGO to explore how civilians perceive their roles in conflict, focusing on the IHL doctrine of "direct participation in hostilities". Students and faculty conduct on-the-ground factfinding in a number of post-conflict situations and prepare reports for the $\mathrm{NGO}^{4}$

- Perhaps most common of all IHL clinical engagements, students at numerous American law schools work with law firms and criminal defence lawyers to provide pro bono legal research for detainees at the Guantanamo Bay Naval Facility. They conduct research, draft legal arguments and monitor proceedings in military commissions and habeas corpus cases in the Court of Appeals for the DC Circuit. ${ }^{5}$

1 This work is carried out by the Emory International Humanitarian Law Clinic: http:/law.emory.edu/ academics/clinics/international-humanitarian-law-clinic.html.

2 See UCLA School of Law International Justice Clinic, Victim Participation and the Extraordinary Chambers in the Courts of Cambodia: Involvement of the Cambodian-American Diaspora Community, June 2010, available at: http://cdn.law.ucla.edu/SiteCollectionDocuments/Clinical\%20Program/ECCC\% 20Report.pdf.

3 This work is carried out by the Emory IHL Clinic.

4 This work is carried out by the University of California, Irvine International Justice Clinic: www.law.uci. edu/academics/real-life-learning/clinics/international-justice.html.

5 The Emory IHL Clinic worked with four different law firms and one NGO representing detainees at Guantanamo Bay between 2007 and 2011. Other clinics have also worked on Guantanamo issues. See, e.g., Carol Rosenberg, "FOIA Suit Reveals Guantánamo's 'Indefinite Detainees”, Miami Herald, 17 June 2013, available at: www.miamiherald.com/2013/06/17/3456267/foia-suit-reveals-guantanamos. html; Gautam Haithi, "Duke Law Students Work on Guantanamo Prisoner Defense", The Duke Chronicle, 15 January 2014, available at: www.dukechronicle.com/articles/2014/01/15/duke-lawstudents-work-guantanamo-prisoner-defense; Ami Dodson, "William \& Mary Law School Students Assist the Pentagon in Prosecuting Guantanamo Detainees", William \& Mary Law School, 21 January 2010, available at: http://law.wm.edu/news/stories/2010/malone-guantanamo-project.php. 
The turn to such clinical IHL work does not arise out of a vacuum. Before the 1990s, IHL rarely appeared in American law school curricula. It made its primary appearance, where it appeared at all, as a small component of a public international law, human rights or use of force class. The past two decades, in contrast, have seen a growth in the variety and reach of IHL courses in the United States, with over forty law schools in the country offering a dedicated course on IHL, sometimes presented as a stand-alone offering and sometimes packaged with courses on national security, human rights, international criminal law or related fields. ${ }^{6}$ Academic, policy and military communities engage one another extensively on IHL and related issues, and law school faculty and students address contemporary problems in articles and symposia and other fora, contributing to the discourse about and development of the law. Just as much of the rest of the law school curriculum nationwide has grown beyond the classroom-with clinical work in community economic development, capital punishment, environmental law, immigrant rights, domestic violence, human rights, appellate advocacy, civil rights and much more-so too has the widespread engagement with the legal consequences of armed conflict.

This article argues that enabling students to participate directly in the development and application of IHL in concrete "real world" settings - from training to research and fact-finding, litigation to high-level advocacy, and many spaces in between-does far more than just contribute to these students' development as effective, reflective lawyers, certainly a key goal of any clinical environment. Such work also provides students with insights into issues of professional responsibility, ethics and general lawyering skills that are naturally portable to other areas of a student's future career. Beyond that, clinical IHL work prepares students for careers in IHL and broadens their exposure to alternative ways of seeing law in action. It thus expands student understanding of the complexity, institutions and enforcement of IHL in a way that library research and classroom discussion, as critical as they are, cannot fully achieve.

At the same time, IHL clinic assistance to entities working on issues related to international law and armed conflict, accountability and protection - whether NGOs, international tribunals, domestic courts, militaries, law firms or others goes beyond contributions to the implementation and enforcement of IHL in the specific area of any particular project. Clinical work connects classroom learning to work in IHL in a way that builds the knowledge, networks and skills essential to effective dissemination and promotion of IHL, a Geneva Convention obligation that undergirds the entire framework of IHL. ${ }^{7}$ And, as we argue here, clinical IHL work contributes directly to that obligation of promotion. Altogether, IHL clinical work matches clinical pedagogy with contemporary issues in armed

6 This number and information about IHL in US law schools past and present is based on data found in ICRC reports on teaching IHL in US law schools. See, e.g., American University Washington College of Law and International Committee of the Red Cross, Teaching International Humanitarian Law at U.S. Law Schools, available at: www.wcl.american.edu/humright/center/documents/IHLSurveyReport.pdf. Geneva Conventions I-IV, Arts 47, 48, 127 and 144 respectively. 
conflict to deepen students' law school experiences and enables them to engage in the IHL goals of promotion, implementation and enforcement.

The first part of this article describes the work of two clinics: the Emory International Humanitarian Law Clinic and the University of California, Irvine's International Justice Clinic. After a brief discussion situating these clinics in the context of clinical education's development over the past few decades, this part introduces the goals of clinical IHL work and highlights both IHL-specific and general lawyering skills that the clinics aim to impart to students. Finally, this part explores the role of the clinical seminar that accompanies the project-specific work and forms an essential component of the clinical experience. The second part examines several particular challenges of IHL clinical work that stem from the different constituencies involved in the application, implementation and enforcement of IHL; from IHL's balancing of military necessity and humanity and how that plays out in the work of different organizations and the protection of persons in conflict; and from the complicated mix of law and policy inherent in the current discourse on IHL.

\section{The clinical experience and IHL}

\section{The development of legal clinics in US legal education}

Clinical education in the United States has its roots in a movement designed not merely to provide students with experiences in the field, or to offer legal services to the disadvantaged, or to hone critical skills in areas such as deposition, interviewing and advocacy, although it often includes each of those components. Clinical models grew out of a basic recognition that rigorous academic work, as critical as it is to developing familiarity and ease with legal principles and theory, does not adequately introduce students to the complexity of legal practice. Traditional curricular work, drawn from the case method study of law, revolved around - and continues to revolve around-appellate cases, designed to focus attention on the core legal issues that might be at the centre of particular disputes. As a leading visionary for clinical education, Jerome Frank, put it in 1947 (years before the clinical movement truly launched in the United States), "with a very few notable exceptions, the kind of so-called 'law' taught by most professors in the schools consists of deductions from upper-court opinions". ${ }^{8}$ Thus, we have the casebook, the heavy tomes designed by law professors in every legal field and read by all law students in the United States. The casebook has long been a central tool for training students to identify substantive and procedural legal norms.

But there are certain critical tools that the case method cannot reach. In particular, the casebook presents disputes as a series of found facts with disputes over them and the law applicable to them already resolved by various levels of 
administrative and judicial systems. Consider, for instance, the various treatments of the Israeli fence or separation barrier by the International Court of Justice and the Israeli High Court of Justice. ${ }^{9}$ An examination of the cases demonstrates different approaches to IHL interpretation and enforcement, a useful way to explore the substance of the law. But the opinions themselves, as presented in casebooks, do not give students the tools to understand how and why the policy-makers and lawyers collected (or neglected to collect) facts to support their positions, advocate or defend against claims, consider the long-term implications of their positions, strategize their case, and so forth. They do not impart insights about how advocates work with or against one another, particularly when they represent or defend opposite sides of an armed conflict, or how activist lawyers may work with or against governments. They do not help students understand the choices advocates sometimes have to make regarding when and how to challenge a decision, and how those choices might affect future options for advocacy and legal work. They do not impart a substantial amount of learning about the practice of IHL because casebooks very rarely, if at all, present law students with the extensive range of challenges that lawyers face in practice: how to gather the facts necessary to building a legal case, how to deploy those facts consistent with the legal norms at issue, how to work with clients and adversaries in advancing a case or counselling a course of action. The growth of clinical education has shown that the casebook is but one tool in developing wellrounded curricula and, ultimately, well-rounded practitioners in law and other related fields.

Early clinical work in US law schools grew out of the vision of Professor Frank and, beginning in the 1960s, a mix of social justice and community service goals, particularly in the context of low-income communities. By 1980, leading clinicians would "argue ... that clinical education was not merely a return to apprenticeship or a cure for third-year boredom, but a vehicle by which students could gain a 'broader view' of the legal problems and processes studied in the classroom and work for the reform of those processes". ${ }^{10}$ Within a decade, "clinical legal education experienced a shift away from a justice mission and towards an emphasis on lawyering skills such as interviewing, negotiation, oral advocacy, and brief writing". ${ }^{11}$ Today, although the social justice vision of clinical education may still predominate, students at most American law schools have the opportunity to take clinical courses that focus on substantive legal problems as well as lawyering skills through simulations, intensive brief and motion-writing, and other exercises.

9 See Supreme Court of Israel, Beit Sourik Village Councilv. The Government of Israel, HCJ 2056/04, 30 June 2004; International Court of Justice, Legal Consequences of the Construction of a Wall in the Occupied Palestinian Territory, Advisory Opinion, 9 July 2004, ICJ Reports 2004, p. 136.

10 Laura G. Holland, "Invading the Ivory Tower: The History of Clinical Education at Yale Law School", Journal of Legal Education, Vol. 49, 1999, p. 525 (referring to the work of Dennis Curtis and Stephen Wizner, pioneering clinicians at Yale Law School).

11 Deena R. Hurwitz, "Lawyering for Justice and the Inevitability of International Human Rights Clinics", Yale Journal of International Law, Vol. 28, 2003, p. 524. 
Given the social justice and law reform objectives that became a central part of American clinical legal education, along with the expansion of international human rights law beginning in the 1960s, it was natural that human rights clinics would eventually enter the field. Dozens of law schools across the country have some form of human rights clinic today, alongside the traditional clinical offerings. Human rights clinics give students the opportunity to partner with leading NGOs, engage with human rights institutions of the United Nations (UN) and treaty monitoring bodies in a variety of fields, conduct fact-finding at home and abroad, and write reports, lobby governments and pursue other forms of advocacy. But while students in human rights clinics "learn many of the same skills ... as they would in traditional clinics", the different "instrumental particularities of human rights lawyering" lead many human rights clinics to develop a "norm-centered pedagogy". ${ }^{12}$ In other words, much like the IHL clinical work described below, human rights clinics often prioritize a mission of promoting particular human rights regimes and rules, while they less often pursue the traditional clinical commitment to particular clients, whether individual or organizational. ${ }^{13}$

\section{Introduction to Emory's IHL Clinic and UC Irvine's International Justice Clinic}

It is partly against this background that clinical work in IHL developed, often in the context of existing human rights clinics. One strand of clinical engagement began with the emergence of international criminal law in the 1990s and the establishment of the tribunals in The Hague, triggering a broad focus on accountability. ${ }^{14}$ As new institutions applying IHL entered the scene in full force in the 1990s, IHL jurisprudence followed suit: the ad hoc UN war crimes tribunals for the former Yugoslavia (ICTY) and Rwanda (ICTR); the conclusion and subsequent entry into force of the Rome Statute for the International Criminal Court (ICC); hybrid national-international tribunals for Sierra Leone and Cambodia; and other specialized war crimes chambers, panels or commissions in places like Sarajevo, Belgrade and Dili, East Timor. UN and treaty-based human rights bodies and regional human rights courts began addressing (or avoiding) IHL issues as well. ${ }^{15}$ Leading NGOs, enjoying significant momentum stemming from their influence over the development of the Ottawa

12 Ibid., pp. 532-533.

13 This fact led Deena Hurwitz to suggest that "[h]uman rights norms or principles can even be the underlying 'client"'. Ibid., p. 533 (emphasis in original).

14 The war crimes projects at Case Western University Law School (http://law.case.edu/centers/cox/warcrimes/content.asp?content_id=128) and American University Washington College of Law's War Crimes Research Office (www.wcl.american.edu/warcrimes/) were early entrants into the field.

15 See, e.g., Report of the International Commission of Inquiry on Darfur to the United Nations SecretaryGeneral, 25 January 2005, available at: www.un.org/News/dh/sudan/com_inq_darfur.pdf; InterAmerican Court of Human Rights, Juan Carlos Abella v. Argentina (La Tablada Case), Case No. 11137, 18 November 1997; European Court of Human Rights, Al-Skeini and Others v. The United Kingdom, Application No. 55721/07, 7 July 2011. 
Landmine Ban Convention in 1997 and the Rome Statute in 1998, developed programmes dedicated to State and individual accountability for IHL violations, such as Human Rights Watch's International Justice division, the Open Society Justice Initiative, and Amnesty International's Campaign for International Justice. Over the course of two decades, IHL entered the mainstream of public international law and human rights advocacy, building on the long-standing work of the International Committee of the Red Cross (ICRC) and national Red Cross and Red Crescent societies, and law schools followed close behind.

A second strand of clinical engagement first accompanied litigation over the status of detainees held at Guantanamo Bay Naval Facility and expanded with the enormous set of legal issues that followed the September 11 attacks and the wars in Afghanistan and Iraq. Critical issues of IHL became central points of dispute, advocacy and litigation, lead among them the status and treatment of detainees, the length of detention, the prosecution of detainees, the categorization of armed conflicts, and the use of unmanned aerial vehicles (UAVs, or drones) to combat terrorism. ${ }^{16}$ Scholarship in IHL expanded exponentially alongside a vast array of legal disputes. The US Supreme Court entered the fray repeatedly, guaranteeing attention by American legal academics, even those without a background in international law. As with human rights, then, the focus on IHL in a clinical setting became a natural result of the legal activity among governments, international organizations, courts and other actors.

With terrorism and US military engagements putting IHL on the front page, the Emory IHL Clinic, founded in January 2007, took classical clinical goals - giving students opportunities to engage in hands-on, "real world" work and providing assistance to organizations - and put them into practice specifically in a comprehensive spectrum of IHL activities: dissemination, training, implementation and enforcement. Under direct clinical faculty supervision, each student in the Emory IHL Clinic provides assistance to one of many organizations with which the clinic collaborates. Students research complex contemporary issues, draft memoranda, briefing papers, reports and other written products, and communicate directly by phone and email with an attorney or supervisor at the relevant organization to report on and discuss their work. During the regular clinical classroom meeting, students learn the fundamentals of IHL, discuss application of IHL's core principles to contemporary conflicts and challenges, and present their work to their fellow students, describing their assignments and highlighting the key legal issues and challenges.

Unlike most human rights or international law-oriented clinics, which use a team approach in which most or all of the clinic students work together on one or two major clinic projects, the Emory IHL Clinic takes an alternative approach aimed at maximizing the diversity of student experience and the number of entities the

16 The US Supreme Court has rendered numerous opinions on detainee status and prosecution since 2004. In addition, two federal district courts have dismissed cases related to the killing of Anwar al-Aulaqi: $\mathrm{Al}$ Aulaqi v. Obama, 727 F.Supp.2d (D.D.C. 2010); Al-Aulaqi v. Panetta, DC District Court, 7 April 2014. For a synopsis of the status and results of all habeas cases, see Center for Constitutional Rights, Guantanamo Bay Habeas Decision Scorecard, available at: http://ccrjustice.org/GTMOscorecard. 
clinic can assist. International law is an area in which many students are keenly interested, but few can anticipate or understand what it means to "work in international law" after graduation from law school. This limited perspective is even more pronounced in the area of IHL and other legal issues during armed conflict. With each student in the Emory IHL Clinic working for a different entity (for example, an NGO, an international tribunal, the military, or an expert project or working group), students get an in-depth experience with regard to their own projects and gain a window into the other opportunities and venues through which one can practice international law.

The Emory IHL Clinic focuses on three main substantive priorities: training and education for militaries and organizations involved in armed conflict; the implementation of IHL in US military operations and national security strategy; and accountability for violations of IHL. For example, the Emory IHL Clinic has a long-standing project on military training programmes in the law of war that collects and analyzes information about how countries around the world train their forces in the law of war. ${ }^{17}$ Providing training in IHL is an obligation for all countries as parties to the Geneva Conventions. Understanding how countries do so and the differences in their approaches to this foundational component of military training offers useful insights into the nature, capabilities and operations of the vastly different military organizations around the world.

Second, effective implementation of IHL and international law is essential to lawful and effective military operations and to the protection of civilians and all persons in zones of conflict. To this end, Emory IHL Clinic support for the ICRC customary IHL database of State practice ${ }^{18}$ helps to advance understanding of how States execute their obligations under IHL. As another example, clinic students provide assistance to experts on the UN Committee against Torture, researching and drafting extensive preparatory memoranda for use at the Committee hearings each year. These students have an opportunity to see international law in action by working directly at the intersection of State practice, the international legal regime and the institutions that support it.

Finally, law also depends on enforcement and accountability as key components of ensuring that States and individuals adhere to the law and face appropriate legal consequences for failure to do so. Emory IHL Clinic assistance to international tribunals, military commissions and NGOs focused on accountability and advocacy for accountability contributes to this goal.

The International Justice Clinic at UC Irvine School of Law, established in 2012 and building on the work of its prior incarnation at UCLA School of Law, provides a platform for training law students in the tools of accountability for IHL and other significant international law violations, including violations of

17 This project produced the volume Laurie R. Blank and Gregory P. Noone, Law of War Training: Resources for Military and Civilian Leaders, 2nd ed., US Institute of Peace, Washington, DC, 2013.

18 The ICRC customary IHL database is available at www.icrc.org/customary-ihl/eng/docs/home. The database provides updated information based on and in support of the ICRC Customary Law Study: see Jean-Marie Henckaerts and Louise Doswald-Beck (eds), Customary International Humanitarian Law, Cambridge University Press, Cambridge, 2005. 
human rights law. ${ }^{19}$ The International Justice Clinic approaches IHL clinical education with a particular kind of advocacy in mind: that of the human rights fact-finder who engages with individuals directly affected by IHL and human rights violations and yet also seeks to influence policy change. The International Justice Clinic benefits from partnerships with international and domestic organizations, but it leaves room for independent projects and advocacy-oriented research. The International Justice Clinic also aims to introduce students to the possibility of pursuing IHL and human rights careers in contexts outside of the human rights NGO field where it does most of its work, including government (such as the human rights bureau or legal adviser's office at the US State Department), international organizations such as the UN and its many affiliated agencies, and the private sector, with its increasing focus on corporate social responsibility at an international level.

The International Justice Clinic operates on three levels: first, it provides students with specific projects, encouraging them to take ownership of them and use their initiative to solve problems and design solutions in a teamwork environment. They work in teams of two to four students, conducting factfinding, legal analysis or drafting, depending on the project, under the supervision of faculty and often practitioners in the field. The International Justice Clinic aims to allow students to practise as if they were early associates at a firm or project managers in an NGO. Second, the International Justice Clinic provides space for students to reflect on their work and develop presentation skills, whether in the context of twice-weekly seminar meetings, weekly team supervision sessions or regular interactions with partner organizations. Reflection is, in fact, one of the hallmarks of clinical education. Students are encouraged to develop habits of reflection such that, when they move to a professional practice in the field, they take the time to consider their work product and relationships, analyze strengths and weaknesses, and improve. Third, the seminars enable students to deepen their substantive understanding of IHL and other legal areas and to explore the particular tools that are necessary for human rights and IHL advocacy.

This brief introduction to the two clinics provides the background for the discussion of the clinics' pedagogical goals and methodologies in the next part of this paper, and the presentation of key conceptions and challenges in the third part.

\section{Pedagogical goals}

Clinical programmes typically seek to maximize student ownership of projects and encourage student initiative in the formulation, implementation and presentation of projects. A founding premise of clinical education is that students will learn legal skills best when they deploy those skills in real situations of advocacy, enhanced 
by reflection and by the supervision, instruction and feedback of faculty. Two elements are distinctive for both clinics: first, IHL education through direct participation in its development and enforcement; and second, although both clinics conduct work outside of IHL in related areas such as human rights law, they both consider a critical focus to be the implementation and enforcement of IHL through understanding of and fluency with the many institutions that promote IHL and carry out its core purposes.

\section{Promotion of IHL's core purposes and principles}

IHL regulates the conduct of hostilities and seeks to protect persons and objects affected by armed conflicts. The most obvious goal, perhaps, and the one most often cited by students motivated to work on IHL issues, is its humanitarian purpose: protecting persons who are caught up in the hazards of war. Equally important, however, is the goal of regulating the means and methods of warfare to protect those who are fighting-soldiers and other belligerents-from unnecessary suffering during conflict. Of course, IHL does not seek to inhibit legitimate military operations or prevent the unlawful resort to war (the goal and function of the jus ad bellum); rather, its goal is to ensure that military operations are conducted within the parameters of the aforementioned two protective purposes.

The application and implementation of IHL is often understood to rest on four core principles: military necessity, humanity, distinction and proportionality. This entire issue of the Review is dedicated to understanding and enhancing the obligation of all States to "respect and ... ensure respect for [IHL] in all circumstances". ${ }^{20}$ Although IHL applies only during armed conflict, respecting and ensuring respect for the Geneva Conventions and IHL more broadly is not an activity or an obligation limited to times of armed conflict. It rests in the training and education of military forces; in the dissemination of IHL beyond the military to "civil instruction" programmes, which include government, advocacy, policy circles, and academia; and in the culture of the rule of law that enables advocacy for better implementation of IHL and effective enforcement and accountability for violations of IHL during and after conflict. In the same manner, the two clinics discussed here work to ensure respect for IHL. Working with advocacy organizations and international or hybrid tribunals supports efforts to protect civilians during armed conflict and hold accountable those who violate IHL's central tenets. Developing teaching materials for the incorporation of IHL into other courses at law schools and graduate programmes contributes to wider dissemination of IHL, while projects to enhance and analyze training and education in IHL for militaries go to the heart of the obligation to respect IHL. At the same time, a diverse clinical approach contributing to all of these efforts concurrently creates an environment that mirrors the real world: advocacy must 
coexist with implementation, and accountability must coexist with training and education.

Traditional clinics often pursue a live-client representation model, usually serving specific needs in the local community for individuals and groups. IHL clinical projects may adopt the same representational approach, as in the case of work with detainees at Guantanamo Bay or support for Alien Tort Statute plaintiffs. ${ }^{21}$ Generally speaking, however, the clinics discussed here tend to partner with other organizations on matters of fact-finding, research, training, advocacy and so forth. They adopt a broad view of the structure of the IHL arena and the needs of its key constituents as part of the promotion of IHL. One might say that IHL itself is the "client", 22 but it may be just as accurate simply to note that the clinics discussed here pursue a mandate of IHL promotion.

The International Justice Clinic, for instance, developed a number of projects designed to promote the application of IHL and the expansion of accountability for violations. In one case, several students spent a year conducting research, including interviews with lawyers, diplomats and activists at the Assembly of States Parties of the Rome Statute in The Hague, to develop recommendations for US participation in the first Review Conference of the Rome Statute in Kampala, Uganda, in 2010. ${ }^{23}$ The report ultimately aimed to enhance US participation in ICC activities, if not advocate for ratification of the Rome Statute. In another example, International Justice Clinic students worked with lawyers and scholars from the Open Society Justice Initiative who were developing an approach to hold accountable multinational corporations involved in illicit mining in conflicts in the Democratic Republic of the Congo. ${ }^{24}$ They conducted research but also worked closely with lawyers thinking through legal strategies to hold such actors accountable under IHL, creatively using the model of the war crime of pillage to apply to such behaviour. In a similar example of projects involving broad thinking about the application and implementation of IHL writ large, Emory IHL Clinic students have worked with experts on the UN High Commissioner for Human Rights (UNHCHR) Working Group on the Use of Mercenaries to identify existing legal frameworks and accountability mechanisms for the use of mercenaries and private military and security companies during conflict, and to strategize how such frameworks and mechanisms can be strengthened to ensure better adherence to IHL and better protection for individuals.

21 See Rex Bossert, "UCI Law Students Help Attorney Argue First Case of New U.S. Supreme Court Term", UC Irvine, 4 October 2012, available at: www.law.uci.edu/news/features/2012/1004-ihrc.html.

22 D. R. Hurwitz, above note 11, p. 533.

23 See UCLA School of Law International Justice Clinic, The Road to Kampala: U.S. Participation in the Review Conference of the International Criminal Court, April 2010, available at: http://cdn.law.ucla.edu/ SiteCollectionDocuments/Clinical\%20Program/Road\%20to\%20Kampala\%20FINAL.pdf.

24 See James G. Stewart, Corporate War Crimes: Prosecuting the Pillage of Natural Resources, Open Society Foundations, September 2011, available at: www.opensocietyfoundations.org/sites/default/files/pillagemanual-2nd-edition-2011.pdf. 


\section{Engagement with the institutions of $\mathrm{IHL}$}

The Emory IHL Clinic and the International Justice Clinic both seek to introduce students to IHL in all of the institutions where it is practiced and engaged, especially in governments, militaries, the ICRC, international courts and tribunals, international organizations and human rights NGOs. Partnering with institutions can take different forms. The International Justice Clinic, for instance, may assign students to work on a project co-led by a partner NGO. Clinic students may then conduct on-the-ground fact-finding for a portion of a larger project, feeding their reporting and research into litigation, reporting or other forms of advocacy. In a different approach, each student in the Emory IHL Clinic works with an attorney or other supervisor at one of the entities with which the clinic partners. Using either approach, both clinics provide assistance to and collaborate with the primary organization, rarely taking on client representation themselves. One of the primary pedagogical results of a partnering or assistancebased approach is that students learn about the different institutions and organizations that apply, advocate for and enforce IHL, identify the organizations' goals and agendas, and assess how to provide the most effective assistance possible.

In this environment, students in both clinics must first learn about and understand the organization with which they are working. The organization's goals and priorities serve as an essential basis for all of the students' work, just as they do for the full-time lawyers, policy analysts and others engaged in the comprehensive task of promoting, executing and enforcing IHL. For example, an Emory IHL Clinic student is asked by an NGO to research and analyze the viability of Colombia's prosecutions of sexual violence crimes. Although the facts and the law remain the same from any perspective, it is essential for the student to understand the NGO's perspective - accountability and remedies for victims of atrocities - and how the information will be used - in a communication to the ICC to encourage the prosecutor to investigate those crimes - so as to give the best analysis possible. The very same law and facts might well be presented, analyzed and used differently by an NGO advocating for better accountability from the Colombian government, or by a military training programme using the information as a case study, or by any number of other institutions.

In addition to working with and within institutions, IHL clinical education may introduce students to the critical elements of collaboration and networking in order to build support for IHL-sensitive projects. The International Justice Clinic, for example, conducted a year-long research project looking at a variety of areas related to transitional justice and the conflict in Syria in 2011 and 2012. Working with Syrian activists, the International Center for Transitional Justice and the Open Society Justice Initiative, UCLA Law School students participating in the Clinic helped to organize a workshop in Istanbul, Turkey, to discuss the spectrum of transitional justice options. The workshop aimed not to build a strategy for accountability, but rather to give Syrian activists the space to discuss the range of 
choices they might have available to them in a post-conflict Syria. The project enabled students to collaborate with activists who were thinking specifically about enforcement of IHL, giving them insights into not only the range of enforcement opportunities but also the types of resistance typical in post-conflict situations.

\section{Public international law research and analysis}

The ability to work effectively in the field of IHL depends on a thorough knowledge of public international law and IHL's foundational components: the threshold for triggering application of IHL, core IHL principles, the status of persons, rules for the conduct of hostilities, detention regimes, and accountability for grave breaches and other violations of IHL, to name a few. It also requires an understanding of customary international law and the ways in which general IHL principles, such as the Martens Clause, may be deployed to frame IHL arguments. Different projects require students to apply different aspects of this knowledge, depending on the particular legal issues at the forefront.

Broadly speaking, however, several additional competencies are essential to student and clinical success in this area. First, students need to understand how IHL relates to other international and domestic legal regimes and to recognize when IHL is not applicable. Using IHL when inappropriate can have significant negative consequences, both for people involved in and subject to military operations and for the development of the law. For example, although multinational counterpiracy operations can involve extensive naval capabilities and firepower, the operations are in most cases not governed by IHL because the situation is not an armed conflict. ${ }^{25}$ Applying IHL in such a circumstance would mean that the militaries could use lethal force as a first resort and detain captured pirates without charge, authorities that IHL provides but that are not present in legal regimes applicable in the absence of armed conflict. Second, students need to learn the boundaries between law and policy, boundaries that often can be particularly blurry in the arena of conflict, national security and international law. Drawing these lines is essential for the provision of sound legal advice and analysis and also for the development of an effective advocacy strategy where relevant. Research in the area of targeted killing and UAV strikes, for example, has proved to be particularly challenging and demanding of careful law and policy delineation in this regard. Third, students must understand the roles that different institutions play before, during and after conflict, and learn how those roles may drive an institution's perspective on the application of IHL, effectiveness in using IHL, receptiveness to different types of IHL-based arguments and information, and success in fulfilling its designated mission.

25 See, e.g., Laurie R. Blank, "Rules of Engagement and Legal Frameworks for Multinational Counter-Piracy Operations", Case Western Reserve Journal of International Law, Vol. 46, 2013, pp. 397-409. In addition, as part of the Emory IHL Clinic's work with the Public International Law and Policy Group's (PILPG) High Level Working Group on Piracy, students analyzed the law applicable to piracy and counterpiracy operations, among other topics. 
Beyond these thematic concepts, several of the projects of the Emory IHL Clinic and International Justice Clinic highlight specific IHL and international law competencies. ${ }^{26}$ International law research requires a thorough knowledge of the sources of international law, how they interact, how courts and governments weigh those sources, and where to look for case law and other jurisprudence on issues from IHL to international investment arbitration. Academic courses on international law and related research emphasize these skills. The IHL clinical setting, however, focuses on another set of research skills as well: the gathering and analysis of facts and information about ongoing or recently concluded conflicts, State compliance with international obligations, and the different types of actors in a given situation of conflict. Depending on the nature of the project assignment and the goals of the partner organization, clinic students need to assess what information is needed, the validity of different factual sources, and why certain information is more or less useful.

The International Justice Clinic's work with the NGO AIDS-Free World, examining the international standards for witness protection in cases of sexual violence during armed conflict, highlights these skills. Teams of students explored the problem of witness protection in international criminal justice and the scourge of gender violence in situations of armed conflict through desk research, interviews with officials responsible for witness protection, prosecutors, counsellors and psychologists, investigators and others at the ICTY, ICC and Special Tribunal for Lebanon, and fieldwork in the justice systems of Colombia, Liberia and Sierra Leone. Throughout, the students analyzed whether international legal norms had developed in the context of witness protection or whether they would be better characterized as best practices, and they examined whether the standards developed at The Hague's institutions could be - and were being - applied in the other post-conflict settings.

In a similar manner, students in the Emory IHL Clinic work with the UN Committee against Torture to research conditions in countries appearing at hearings before the Committee and prepare background memoranda for one or more rapporteurs on the Committee. The research is fact-intensive and demands creativity and persistence to track down information about issues of concern to the Committee, such as prison conditions, violence against women, treatment of detainees, or migrant workers. In some cases, the country being researched is embroiled in low-level violence or a more extensive armed conflict, adding to the complexity. Most important, however, is that the clinic student must be able to assess which facts are important and why. This requires an understanding of the Committee's goals and methodology, as well as a broader grasp of what is happening in the country under review. Clinic students also prepare, and include in the background memoranda, extensive questions for the Committee rapporteur to pose directly to the country's representatives at the hearing. Doing so requires that the student analyze and understand what information is needed to assess a

26 A number of projects that highlight the skills discussed in this section involve confidentiality concerns and therefore are not described here. 
country's compliance with international obligations and how to gather, analyze and use that information. This final component of these research competencies lies at the heart of effective international lawyering, whether in the advisory, advocacy or accountability arenas.

With regard to specific IHL questions, the first question, of course, is whether IHL applies at all. Clinic projects require students to delve deeply into multiple layers of analysis following from this question, including, for example: if there is an armed conflict, is it an international or non-international armed conflict; if, how and to what extent does human rights law apply during the conflict; what is the status of persons involved in or harmed by any alleged crimes; and what options are there for jurisdiction over potential IHL violations? Each of these questions - and other IHL legal issues - is complex, and students must focus on sophisticated relationships among these issues in conducting their legal analysis.

Selected projects at the Emory IHL Clinic engage all of these levels of IHL legal analysis and demand careful attention to the precise nature of the question posed by the partner or client organization. For example, clinic students working with the European Center for Constitutional and Human Rights have analyzed the protests in several Arab Spring countries to determine whether the level of violence rose to the threshold of a non-international armed conflict (a determination that then, of course, could frame options for seeking accountability). Doing so not only requires that students be able to present and explain the definition of non-international armed conflict, along with the appropriate jurisprudential analysis and reasoning, but also demands an understanding of what facts and information support or undermine a conclusion regarding the existence of a conflict. Here, of course, is the essence of legal analysis: knowing both the law and its application to the facts in the chaotic and complex reality of the situation on the ground.

Further examples of comprehensive legal analysis are the memoranda that IHL Clinic students have drafted for the Public International Law and Policy Group (PILPG) High Level Working Group on Piracy ${ }^{27}$ and the analyses of domestic and international law governing the activities of private military and security companies (PMSCs) produced for the UNHCHR Working Group on Mercenaries. Research memoranda prepared by Emory IHL Clinic students on numerous topics, including the law governing counter-piracy operations and the use of force against pirates, the recruitment and use of child pirates as a crime against humanity, and the consequences of excessive use of force in the apprehension of pirates, are provided to judicial and government officials in countries prosecuting pirates, such as the Seychelles and Kenya, as part of a toolbox of resources for effective and lawful counter-piracy operations and prosecution of pirates. With regard to PMSCs, IHL Clinic students analyzed the domestic legislation

27 The PILPG Piracy Working Group provides legal and policy advice to domestic, regional and international counter-piracy mechanisms, with the goal of helping to create effective responses to the growing piracy threat. 
pertaining to PMSCs in many countries and how that legislation comports with international treaty obligations and international soft-law commitments. This type of legal analysis, involving the layering of international and domestic law and different types of legal sources, is common in the IHL and international law arenas and is highly complex. Students engaging in this type of analysis learn how to look at an issue from multiple angles and how to assess the weight and value of vastly different sources of law.

Similarly, the International Justice Clinic provided direct support to prosecutors in the War Crimes Chamber in the Courts of Bosnia and Herzegovina in Sarajevo. Following extensive desk research, Clinic students travelled to Sarajevo for discussions with prosecutors and judges at the Chamber as well as journalists, activists, international civil servants, and local leaders in Bosnia. The Clinic produced a series of memoranda for court officials on topics ranging from prosecutorial discretion in international criminal law to lessons from domestic war crimes prosecutions in post-war Germany, Rwanda and Argentina. For instance, one team developed a prosecutors' manual for Bosnian lawyers new to war crimes prosecutions. Another team worked with the lead international prosecutor and others in Sarajevo to develop components of a prosecutorial strategy.

\section{Problem-solving, strategic and tactical thinking}

Academic coursework can bring out the dynamism of IHL. Students doing traditional coursework, whether in lecture courses or seminars, are given the opportunity to explore key cases, problems, rules and theories. They may work through such problems in the context of domestic and international case law or hypotheticals in casebooks or generated by professors. In practice, however, lawyers are not provided with a straightforward question and a stipulated set of facts. They may have to determine what the factual situation involves, identifying in advance what IHL-relevant questions should drive the fact-finding. Once they have a set of facts, they may have to determine which ones are legally relevant and what law applies to the set of facts, and subsequently what course of action might be optimal to ensure enforcement of the law. They may have to choose among domestic and international legal approaches, or between legally binding mechanisms and political bodies under treaties or the UN. They may ultimately determine that the law is insufficient to address their client's needs, if they have a client, or their perception of sound policy. In that case, they will need to think through whether an alternative lawmaking approach-as opposed to lawenforcing - would advance client interests or sound policy.

Clinical work attempts to model as closely as possible the ways in which practicing IHL lawyers address legal problems. Clinical students must think both strategically and tactically in the context of real problems. For instance, in 2011, the International Justice Clinic was presented with an opportunity to develop policy proposals to improve multilateral support of the International Criminal Court. Students and faculty developed a project that would focus on improving 
the support of the key multilateral institution - the UN Security Council - for the work of the ICC. The project required clinic students to think through the nature of the legal relationship between the Security Council and the ICC and identify steps that might improve the likelihood of Security Council support for international justice. Students and faculty conducted dozens of interviews with current and former diplomats, activists in leading NGOs, Court officials, academics and others, and they designed a workshop that brought together thirty thinkers in the field of international politics and justice. The project required students to think strategically about the end goal-a stronger Council-Court relationship - and tactically about the kinds of realistic steps which might achieve that strategic goal. Students also needed to think about enforcement mechanisms and advocacy beyond traditional institutions in IHL such as the military services or domestic and international courts or tribunals. In particular, they not only examined the increased role of IHL enforcement (or international criminal justice) at the UN, but they saw that the tools of such enforcement extend beyond exhortations and rhetoric to sanctions, ICC referrals, logistical and military support for fugitive apprehensions, and much more that falls outside the traditional framework of prosecutions and judicial opinions. The project ultimately resulted in a widely distributed report and a follow-on workshop in Beijing. ${ }^{28}$

\section{Training and education support}

IHL depends for its effectiveness on pre-conflict, pre-mission training and education for militaries in the fundamental principles of IHL and how those principles must be applied during conflict. Every government has an obligation to provide training to ensure that its military personnel understand and can adhere to the law of armed conflict. Under the Geneva Conventions, States are explicitly required to "include the study [of the law of armed conflict] in their programmes of military ... instruction, so that the principles thereof may become known to all their armed forces". ${ }^{29}$ Participating in the promotion of IHL at this stage is a unique experience for law students. So much of law school is about analyzing when the law has been violated, how it can be enforced, where it can be enforced and similar questions, but little if any time is spent on the notion of the lawyer as an adviser. And yet, a significant component of lawyering is giving advice in advance - which certainly encompasses training and education in areas like IHL, where operators have to execute the law without a lawyer's on-the-spot advice to help a client comply with the law and choose the best course of action given the law's parameters. This aspect of lawyering is particularly true in the government and national security arena. 
The Emory IHL Clinic has a long-term project, in partnership with the United States Institute of Peace, to study military training programmes in IHL around the world. ${ }^{30}$ Clinic students also engage directly in finding ways to incorporate IHL and international law into military education in the United States, working with military and civilian faculty at Marine Corps University's Command and Staff College and the Naval War College's Joint Military Operations course. These experiences require extensive thinking about how to present IHL to a non-law audience, albeit one that is the key implementer of IHL's core principles and rules. Students draft IHL-based ethical decision games that challenge military officers at Marine Corps University to think about how IHL can help guide their leadership decision-making process. Students have provided briefing papers and course materials, including discussion questions and answers, on topics such as cyber-operations and the role of transitional justice mechanisms in war termination and the transition to peace, and have developed media questions for use in simulation exercises to challenge the officers to address IHL-related issues in new ways in the course of the exercises. Throughout all of these and other projects, clinic students need to rethink how they conceptualize the law; no longer an analytical framework for the courtroom or the client memorandum, here the law is a tool for helping to enhance the training and education of the very individuals who are tasked with implementing it, who are protected by it, and who can be held accountable for violating it.

\section{Lawyering skills}

Students in the two IHL clinics described here are so immersed in the IHL and international law aspects of their work that they often do not realize that they are gaining and honing valuable lawyering skills that translate to any aspect of legal practice. Such skills are, of course, a hallmark of clinical education, but the varied and non-traditional nature of legal engagement in an IHL clinic can obscure this educational aspect of these clinics. For example, students in the Emory IHL Clinic have the real-world experience of talking with a supervising attorney and getting an assignment for a project. This, of course, is the bread and butter of junior lawyers at law firms and other legal offices, but is not an experience law students encounter often, if at all. Students learn to ask clarifying questions, take notes for future reference, and restate the assignment to ensure that they have the correct information and question before proceeding. Another important legal practice skill is to understand the client, its goals and agenda, and what it needs and wants in the final product. In some ways, this aspect of lawyering is a fundamental shift from the law student experience, in which students pick topics for papers and choose their classes. A student working with a partner or client organization must understand that organization and its role in the broader legal arena; the student who takes an assignment and instead turns it into his or her own project is doing the organization and the clinical experience a disservice. The

30 See above note 17 and accompanying text. 
next step in this linear process of going from assignment to finished work product is to strategize for the most effective research approach.

As the descriptions of clinic projects throughout this article demonstrate, writing is a significant component of the clinical work, reflecting our view of its importance in legal practice. Because of the diverse nature of organizations engaged in IHL and receiving clinic assistance, students must learn to write for many different audiences. The traditional legal memorandum or brief simply does not meet the needs of every situation. Reports, advocacy documents, briefing papers, ethical decision games, strategy memoranda, and case studies all require a range of writing skills beyond those traditionally taught in law school. Students learn to write for non-law audiences, for advocacy purposes and for US and foreign lawyers, and, in particular, to write concisely and effectively about complex legal issues. Finally, students gain valuable experience in presenting information orally. Student presentations and discussions in class are one component of this experience in both clinics, but students in both clinics also engage with a wide range of actors to research, analyze, discuss and strategize about their research and projects.

\section{The clinical seminar and faculty supervision}

Although the clinical projects described here aim to provide the kind of engagement with IHL that closely models the work of practicing lawyers in the field, it remains critical pedagogically for the clinical faculty to provide students with regular, ongoing space to reflect upon their work from academic, ethical, practical and other perspectives. For these purposes, both the Emory IHL Clinic and the International Justice Clinic involve seminars that meet weekly or biweekly. The seminar may focus on a wide range of IHL topics, depending on whether the students have had a previous opportunity to study IHL, human rights, international criminal law and public international law. While each programme may vary its focus according to the clinical work involved, they generally share the following elements.

Both clinics combine elements of a traditional law school seminar with the needs of a clinical meeting. For instance, the clinics meet regularly during the first half of the semester for in-depth classes on IHL, using readings drawn from casebooks $^{31}$ or primary documents to generate discussion about theories, strategies and implications of justice-oriented policies. Lectures and class discussions reinforce the necessary foundations in IHL and human rights law. Current events also provide an excellent lens through which to apply and explore these foundational IHL concepts and to link them to ongoing clinical work. At the same time, students present their current work, sometimes simply to update classmates but also to provide the opportunity to discuss specific problems or

31 Laurie R. Blank and Gregory P. Noone, International Law and Armed Conflict: Fundamental Principles and Contemporary Challenges in the Law of War, Wolters Kluwer, New York, 2013, is the assigned reading for the Emory IHL Clinic. 
lessons that may have arisen in the course of the project work. Presentation not only focuses on speaking and oral advocacy skills but also advances the idea of reflection, giving students the tools to think critically about the work they are doing in the projects. Ideally, the faculty will press the students to think hard about the strategic and tactical choices they are making. Is a particular research approach likely to be successful? Why? Would one policy choice be more consistent with a rule of IHL than another? Is it possible that the law inadequately addresses the particular problem that a client faces? If so, how should we think about the capacity of the law to meet its object and purposes (e.g., civilian protection), and if the law is inadequate, what other kinds of approaches might address client or partner organization needs? These kinds of questions should sit comfortably at the centre of a clinic that addresses IHL, just as similar ones should in other clinical settings.

\section{Conceptions and challenges of IHL clinical work}

Clinical programmes vary across (and within) American law schools, but each clinic commonly presents a particular model of lawyering, depending on the field, the kind of projects pursued or the experience of the professor. For instance, an economic development clinic may focus on transactional lawyering, building deals that advance certain social and legal goals in a particular community. An immigration clinic may focus on asylum claims by those fleeing persecution, which could involve litigation before immigration courts, or such a clinic could focus on longterm detention of immigration claimants, which could put the students in a federal court litigation context. An environmental law clinic may focus on challenging State or local regulations or new development projects with negative environmental impact, which could also involve litigation in State and federal courts. It is easy to go through fields of law and identify the range of professional options that one would want to emphasize for students.

In the context of the variety of work conducted by clinical students working in the field of IHL, one can imagine a number of conceptions of the IHL lawyer that an educator would want to advance. The military lawyer, the NGO activist and the international prosecutor all present very different models that may be difficult to imagine integrating into one clinic. The roles lawyers undertake in the field vary significantly, even when all are using the same vocabulary and arguably working toward the goals of IHL compliance. ${ }^{32}$ A question for the clinical professor is whether to adopt one or more of these models as a dominant one for her or his clinic, and if adopting more than one, determining whether and how they fit together to present a coherent picture for students. What follows are some possible conceptions of the IHL lawyer that might be pursued, and some challenges they pose. 


\section{Promoters of IHL}

The obligation of promotion, which includes dissemination, integration into domestic law and measures to ensure respect, exists in IHL - and in the Geneva Conventions in particular-as an obligation of States to ensure that those carrying out State policy do so within the constraints imposed by the law. One clinical model, therefore, is to assist governments and others in the objective of promotion. But what can this mean in the context of clinical work? How can "promotion" projects be designed so as to benefit student legal education and understanding of the law?

The concept of promotion, more than other concepts, shapes the agenda of the Emory IHL Clinic. Projects vary widely in both the nature of the partner organization (such as the US military versus NGOs engaged directly in criticizing US policy) and the goals of the student's work (such as assisting the defence counsel at the US Military Commissions or at the Special Tribunal for Lebanon versus working with NGOs to advocate for accountability for sexual violence, crimes against humanity and torture). Indeed, in such a setting, it is the effective use and implementation of the law that forms the common thread. But highlighting that thread requires a direct and purposive engagement with that conception of IHL and of law in general to ensure that students continually see the big picture beyond the all-consuming specifics of their individual projects.

Furthermore, since the clinics discussed here - not to mention many human rights clinics - are not client-driven, or at least not principally clientdriven, IHL clinicians need to balance the students' promotional roles with the need to give them space to be critical of the law itself. One of the challenges that a clinic might face could be thought of as the challenge of legal change. IHL, like all bodies of law, is not perfect. Some of its standards are vague and subject to competing interpretations. Some may find the balance between military and humanitarian considerations to be weighted too much in favour of the former over the latter. Others may see the law as, despite its objectives, undermining civilian protection. A question faced by any clinic engaging in IHL work is whether its work can both promote and critique the law. A clinic should be able to do both: to promote the rules and values of IHL while also critiquing its application, scope and even specific rules in order to maximize the student educational experience. It may promote IHL by advocating new norms of IHL; this is something that, putting aside the merits of such weapons, the Harvard Human Rights Clinic is doing in the context of autonomous weapons, as it conducts research and advocates for a new instrument in that specific field. ${ }^{33}$ In those situations, how does a clinic both promote IHL and seek to go beyond it? Does "promotion of IHL" allow room for efforts to challenge existing law and offer possibilities for changing it? 


\section{Promoters of civilian protection}

Many would argue that one of the great challenges of contemporary conflict and the law governing it is the protection of civilians. IHL results from negotiations among governments that approach armed conflict from a variety of perspectives, with a great diversity of capabilities, and based on a spectrum of experiences with armed conflict itself. The result is a balance, as it is often said that IHL involves weighing military necessity and humanitarian requirements. ${ }^{34}$ Take, for instance, the rule of proportionality, according to which attacks causing civilian harm "which would be excessive in relation to the concrete and direct military advantage anticipated" 35 are forbidden. This is a challenging standard of IHL, for its breadth and scope are subject to a dizzying array of alternative interpretations. On the one hand, an IHL clinic should aim to promote civilian protection. On the other, one of the fundamental truths about IHL is that it does not proscribe all killing and all harm; it recognizes that non-combatant death, injury and damage may fall within lawful boundaries.

The clinical educator needs to remind students that the legal qualification of a killing under IHL, for example, may diverge from sound policy or moral choice, and is fundamentally different than the legal qualification of a killing outside of an armed conflict in a law enforcement paradigm in which IHL does not apply. This is an important lesson for a student who must choose whether to make legal arguments, policy arguments or moral ones, and must learn that existing law does not always produce what may be the most desirable outcome. In addition, this is an area where the tensions between advocacy and law, between an organization's goal and its legal options, may be most evident. For example, when an Emory IHL Clinic student provided assistance to an NGO exploring accountability options for victims of US drone strikes in Pakistan, research demonstrating that civilians are the victims of many such strikes was not sufficient. Rather, because IHL forbids excessive civilian harm (in relation to the military advantage of an attack) - not all civilian harm - the student had to provide careful legal advice to the NGO to ensure that its advocacy would be based on law, not mere first impressions, which thus framed the types of legal and policy advocacy available to the partner NGO.

\section{Promoters of combatant protection}

Is there room for clinical work that focuses on the protection of combatants? Could this apply not only in the context of people hors de combat and prisoners of war but also to the prevention and prohibition of unnecessary suffering? To the extent that

34 See, e.g., Yoram Dinstein, The Conduct of Hostilities under the Law of International Armed Conflict, Cambridge University Press, Cambridge, 2004, p. 17, explaining that IHL "takes a middle road, allowing belligerent States much leeway (in keeping with the demands of military necessity) and yet circumscribing their freedom of action (in the name of humanitarianism)".

35 Protocol Additional I to the Geneva Conventions of 12 August 1949, and Relating to the Protection of Victims of International Armed Conflicts, 8 June 1977, 1125 UNTS 3 (AP I), Art. 51(5)(b). 
we are not doing this now, why not, and is there room for change? In the past, work on weapons and prohibitions or restrictions of certain weapons would have fallen within this category; the prohibitions on certain weapons grow directly from IHL's prohibition against unnecessary suffering or superfluous injury. ${ }^{36}$ Today, however, many efforts to ban or restrict weapons stem from and focus on the need to protect civilians from the effects of those weapons, whether cluster munitions, landmines, incendiary weapons or other means of warfare.

Another aspect of protecting combatants, however, lies squarely in the training and education aspect of IHL clinical work. IHL plays a fundamental role in protecting belligerents not only physically, but morally as well. As Telford Taylor, the US Chief Prosecutor at Nuremberg, eloquently explained:

War does not confer a license to kill for personal reasons - to gratify perverse impulses, or to put out of the way anyone who appears obnoxious, or to whose welfare the soldier is indifferent. War is not a license at all, but an obligation to kill for reasons of state; it does not countenance the infliction of suffering for its own sake or for revenge.

Unless troops are trained and required to draw the distinction between military and nonmilitary killings, and to retain such respect for the value of life that unnecessary death and destruction will continue to repel them, they may lose the sense for that distinction for the rest of their lives. The consequence would be that many returning soldiers would be potential murderers. ${ }^{37}$

The role of IHL in protecting soldiers and enabling them to segregate their role and actions as soldiers from their broader roles and obligations as members of society is critically important and enables service men and women to return from combat and reintegrate into society effectively. Clinical work that enhances IHL engagement in military education and training contributes to this essential and often overlooked goal.

\section{Promoters of specific clients}

As described above, much of the work pursued by the Emory and UC Irvine clinics focuses on policy or legal advocacy without individual clients. But an entirely different model might focus on the representation of specific IHL clients: victims of grave breaches, defendants in war crimes trials, or organizations seeking the assistance of legal advocates in political or treaty bodies. An IHL clinic should leave room for this kind of client representation - but it does present a variety of challenges. For instance, can a clinic represent both civilian victims and militaries

37 Telford Taylor, "War Crimes", in Malham M. Wakin (ed.), War, Morality, and the Military Profession, Westview Press, Boulder, CO, 1979, p. 429. 
or military officers, even when neither have any relationship to one another and the projects or representations pose no formal conflicts of interest in the sense of professional responsibility? What kinds of conflicts might arise, if any, and how might such concurrent representations adversely affect each other? What criteria should govern those choices? Clinical faculty need to ensure that the clients, partners and issues chosen for projects present students with a coherent understanding of the role that IHL plays in contemporary conflict, which may enable the creation of a diverse docket of projects. However, a faculty member who wants to focus on one particular aspect of IHL enforcement - such as war crimes defence work, fact-finding and reporting in conflicts, prosecutorial support or policy advocacy - will avoid knotty conflicts within the docket and will merely need to identify other ways to bring into the classroom the full set of IHL work.

Another component of the choice of partner organizations and clients involves how broadly to extend the work of an IHL clinic. The Emory IHL Clinic provides assistance to a number of organizations whose primary work is not directly IHL but is rather more tangentially related, such as the UN Committee against Torture, the Special Tribunal for Lebanon or the PILPG High Level Working Group on Piracy. Determining how and when that relationship with IHL is an appropriate one for an IHL-centred clinic can be a challenging process. The Emory IHL Clinic's work with these organizations fits directly into the pedagogical goal of giving students an opportunity to do real-world international lawyering. In many ways, therefore, the Clinic's overall parameters are to work with organizations that are engaged directly with issues related to international law and armed conflict. These parameters naturally encompass many issues of human rights, jus ad bellum, national security law, criminal law and other topics. These "expanded" relationships or projects give students an opportunity to learn how IHL or similarly focused bodies also have to incorporate other legal regimes into their work and address a host of "mundane" legal issues. For example, the Emory IHL Clinic's work for the Special Tribunal for Lebanon has involved fair trial rights and evidentiary issues, which may not be issues that students first think of when they envision working in an IHL clinic. However, these projects enable students to see the many layers of law involved in enforcing international law, and how they interrelate; indeed, foundational rule of law and criminal law issues are central to the practice of all of the international criminal tribunals. Similarly, as noted above, one important aspect of IHL lawyering is being able to identify when IHL does not apply or is not the appropriate legal framework; projects that operate on the "fringe" of IHL provide exactly that opportunity.

\section{Promoters of human rights}

For many years, scholars and lawyers in and out of government have been discussing the extent to which IHL is a lex specialis and displaces, or otherwise offers different norms than, human rights law. Some clinics may seek to apply IHL norms in human rights contexts (regional courts and commissions, for instance). For example, issues related to Guantanamo have arisen in the context 
of the Human Rights Council, the Human Rights Committee of the International Covenant on Civil and Political Rights, the Committee against Torture, the InterAmerican Commission for Human Rights and other human rights-oriented institutions. The location of such claims forces students and faculty to think through how a body of law that developed outside the human rights framework can be interpreted and applied by human rights institutions. One challenge for a clinic is to consider whether to help advance the development of IHL in human rights bodies or to resist that trend. In practical terms, it is probably an unstoppable trend, so the question for the committed IHL clinician may not be whether but rather how to engage with it.

\section{Promoters of accountability}

A final conception of the IHL lawyer here may be as a promoter of accountability. The accountability model would put grave breaches and the enforcement of IHL norms at the centre of a clinical agenda. Without a doubt, accountability is essential to an effective body of law, and a clinical agenda that focuses on accountability offers students many ways to explore how IHL can be enforced, the challenges to effective enforcement and the limits of accountability mechanisms. At the same time, however, IHL is about far more than accountability - so the accountability-focused clinician should think about how to ensure that students gain access to the broader picture of IHL dissemination and implementation.

An accountability-focused clinic triggers valuable conversations around the notions of legal and political or moral responsibility. Presently, for instance, there is considerable debate over a series of acquittals in the ICTY. ${ }^{38}$ It may be that these officials deserved acquittals - that is for a separate debate - but the legal notion of acquittal does not equate with a lack of other forms of responsibility. It may be that the officials committed acts or omitted to take action that led to (or were themselves) violations of IHL, but not subject to prosecution or simply difficult to investigate or prosecute. Or officials may create governmental systems that fail to restrain violations of IHL, and yet such systems may not present individuals amenable to prosecution. The trouble with a clinical programme focused solely on investigations and prosecutions in domestic or international courts is that it may inadvertently neglect these broader questions about the structure of IHL compliance. $^{39}$ In that case, faculty should ensure that students see the broader picture of compliance beyond prosecution.

38 ICTY, Prosecutor v. Ante Gotovina and Mladen Markač, Case No. IT-06-90-A, 16 November 2012, and Prosecutor v. Momčilo Perišić, Case No. IT-04-81-A, 28 February 2013.

39 As an example of the challenges posed by bringing the operational realities of armed conflict into the courtroom, see the report published by the Emory IHL Clinic on the discussions at an experts' roundtable on the Prosecutor v. Ante Gotovina case before the ICTY: Emory IHL Clinic, Operational Law Experts Roundtable on the Gotovina Judgment: Military Operations, Battlefield Reality and the Judgment's Impact on Effective Implementation and Enforcement of International Humanitarian Law, 2012, available at: www.law.emory.edu/fileadmin/NEWWEBSITE/Centers_Clinics/IHLC/Gotovina_Meeting Report.pdf. 


\section{Conclusion}

IHL is a well-established field, with its roots in nineteenth-century lawmaking. But it is also a dynamic field, expanded by the addition of international and domestic fora for accountability and advocacy. With the pace of technological development, it will remain that way going forward. Its central legal norms are found in the 1949 Geneva Conventions and their 1977 Additional Protocols, and a series of other codifications in areas such as cultural property, conventional weapons and torture, for example, have expanded the reach of the law since the 1970s. International criminal law itself, with roots in Nuremberg and Geneva, nonetheless has only become a major field of practice since the middle of the 1990s. All of this simply highlights a basic fact about IHL: it continues to develop by virtue of court interpretations, customary international law, advocacy and even negotiations in related areas. A steadily growing list of actors is deeply engaged in enforcement, advocacy, education, policy-making, training, implementation and legal interpretation of IHL. A mere glance at the major newspapers on any given day points to an array of issues that invoke or touch on IHL in some way.

It is this very dynamism and vulnerability that makes IHL such a worthwhile choice for clinicians, giving students the opportunity to see first-hand that law is malleable, constantly interpreted, and subject to debate and controversy - and perhaps most importantly, to see that they can engage with its norms and institutions and play a part, if only a small one, in helping to promote and even shape it. The two clinics discussed here offer robust mechanisms for IHL clinical work and for the students engaged in such work to participate directly in pursuit of the goal in Article 1 common to the four Geneva Conventions of 1949: "to respect and to ensure respect [for IHL] in all circumstances". 